Reprod. Nutr. Dévelop., 1985, 25 (6), 1083-1099.

\title{
Proteins in the digesta of the pig: amino acid composition of endogenous, bacterial and fecal fractions
}

\author{
J.-P. LAPLACE, Béatrice DARCY-VRILLON, Yvonne DUVAL-IFLAH (*), \\ P. RAIBAUD $\left({ }^{*}\right)$
}

with the technical assistance of Françoise BERNARD, Régine CALMES and P. GUILLAUME (*)

Laboratoire de Physiologie de la Nutrition

(*) Laboratoire d'Ecologie microbienne,

I.N.R.A., 78350 Jouy-en-Josas, France.

Summary. When studying digestibility, the respective parts of the exogenous, endogenous and bacterial fractions in the digesta or feces must be measured. The proportions of proteins from different sources may be estimated by comparing their amino acid composition with those of reference sources. This study describes the composition of endogenous and microbial proteins, i.e. meconium of piglet small intestine and colon, axenic piglet feces, bacteria isolated in the feces of pigs receiving a standard (cereal-based) or a purified diet, and pure culture of Escherichia coli. The composition of monoxenic piglet feces and of feces of conventional pigs fed the two types of diets have also been studied. The data on 17 amino acids were used to make overall comparisons of compositions, using the method of $\chi^{2}$ distances and factorial correspondance analysis. The composition of exclusively endogenous products differed somewhat from that of samples (mucus, mucosa) usually considered as representative of that fraction. In conventional pigs, the major part of fecal proteins was composed of bacterial protein. Accurate estimation of these was difficult : diaminopimelic acid assay gave an estimate of $65 \%$ bacterial protein, while in the same experimental conditions $\chi^{2}$ distance gave an estimate of $90 \%$.

\section{Introduction.}

The estimation of fecal or ileal digestibility is a convenient way of evaluating the functioning of the digestive tract. The material collected is a mixture of variable proportions of fractions of exogenous (dietary), endogenous (exported by the animal itself) and bacterial (saprophytic flora of the host animal digestive tract) origin. For a good assessment of the digestive utilization of the diet, particularly of proteins, these different fractions must be measured.

Isotopic labelling techniques using ${ }^{15} \mathrm{~N}$ (Souffrant, Köhler and Gebhardt, 1982) aid in determining the endogenous nitrogen of digestive contents. Various other methods employing such markers as diaminopimelic acid (Synge, 1953) or 
nucleic acids (Smith, 1969) are used to estimate the proportion of bacterial protein. These techniques cannot be used routinely for digestibility studies. However, the proportions of the various fractions may be estimated by computation based on a study of their amino acid composition. The composition of the mixture (the digesta collected in a given situation) is compared to the composition of endogenous and bacterial reference fractions. This approach has already been used by Darcy, Laplace and Duée (1983) with a limited number of reference protein compositions. However, it is evident that the validity of the computed estimates depends on the number and quality of the reference compositions.

The aim of the present work was to study the amino acid composition of a wide range of materials closely representative of endogenous and bacterial fractions and to compare these compositions to conventional mixed sources.

\section{Material and methods.}

\section{1. - Protein sources used.}

a) Meconium of new-born piglets. Five piglets were killed by cervical dislocation at birth. After the abdomen had been opened and the small and large intestines isolated by clamps, the meconium was collected separately in the two compartments but pooled for the 5 animals $(\mathrm{Mg}$ : samples from small intestine ; $\mathrm{Mc}$ : samples from the cecum-colon).

b) Feces of axenic piglets. The feces of axenic piglets were collected from subjects deprived of colostrum and raised in an isolator. The five samples were obtained in the following conditions :

$A_{1}$ : axenic 1 : mixed feces of two 24 -hour old piglets ;

$A_{2}$ : axenic 2 : mixed feces of two 48 -hour old piglets (same piglets as $A_{1}$ ) ;

$A_{3}$ : axenic 3 : feces of a 3 -day old male ;

$A_{4}$ : axenic 4 : feces of a 2 -day old female ;

$A_{5}$ : axenic 5 : mixed feces of three 2 -day old piglets of both sexes.

c) Feces of monoxenic piglets. The feces of piglets kept in an isolator were sampled after inoculation with a strain of Escherichia coli C5148 in the following conditions :

$\mathrm{I}_{1}-\mathrm{I}_{2}$ : same piglet as the axenic 4 sample; feces collected at 5 days of age ( 2 collections) less than $24 \mathrm{~h}$ after inoculation ;

$\mathrm{I}_{3}-\mathrm{I}_{4}$ : another female piglet collected at 3 days of age (first collection) and 5 days of age (second collection), i.e. respectively less than $24 \mathrm{~h}$ and less than $72 \mathrm{~h}$ after inoculation ;

$I_{5}-I_{6}$ : another female inoculated at 5 days of age; feces collected $24 \mathrm{~h}\left(\mathrm{I}_{5}\right)$ and $48 \mathrm{~h}\left(\mathrm{I}_{6}\right)$ after inoculation :

$I_{7}$ : another female inoculated at 5 days of age ; feces collected 3 days after inoculation ;

$I_{8}-I_{9}:$ two males collected at 5 days of age, 3 days after inoculation ;

$I_{10^{-}} I_{11}$ : another male inoculated at 5 days of age; two assays of a mixture of feces sampled between $24 \mathrm{~h}$ and 4 days after the inoculation. 
d) Feces of holoxenic pigs. These feces were collected from growing pigs receiving either a standard diet of $60 \%$ barley, $15 \%$ corn, $15 \%$ soyameal and $6.5 \%$ lucerne meal or a semi-synthetic diet of $68.3 \%$ purified cornstarch and $21.6 \%$ fish meal (Darcy, Laplace and Duée, 1982). Two pigs (live weight : 55 and $57 \mathrm{~kg}$ ) were given the standard diet and two others (live weight : 47 and $48 \mathrm{~kg}$ ) the semi-purified diet. The samples collected with the standard diet were termed $F_{s}$. Six samples $\left(F_{s} 1\right.$ to $\left.F_{s} 6\right)$ were taken from one pig and three $\left(F_{s} 7\right.$ to $\left.F_{s} 9\right)$ from the other pig. The samples from animals eating the semi-purified diet were termed $\mathrm{Fp}$. Two fecal samples were taken from each animal (Fp10 to Fp13). The pigs were adapted to the diet for at least 14 days before the fecal samples were taken; the samples were collected during defecation by the animal. One part was deep-frozen until assay; the rest was used immediately to isolate fecal bacteria.

e) Bacteria. A series of differential centrifugations (see below) of the feces sampled in the above conditions gave a bacteria-rich fraction for nitrogen and amino acid assays. Bacterial isolates $B_{1}$ to $B_{13}$ corresponded to feces samples $F_{1}$ to $F_{13}$ of the four pigs fed the two diets.

In addition, a pure culture of the E. coli strain used for inoculation (sample E.C.) was made in order to collect enough bacterial material.

2. - Separation of fecal bacteria. - Following the work of Mason (1969), later applied to the pig (Mason, Just and Bech-Andersen, 1976), fecal bacteria were separated by differential centrifugation. This methodology, checked at each stage by direct microscopical examination, was as follows : $50 \mathrm{~g}$ of freshly voided feces were homogenized in 1 I of saline $(9 \% \mathrm{NaCl})$ and ground in an Ultra-turrax. After $20 \mathrm{~min}$ sedimentation, the supernatant was centrifuged $250 \times \mathrm{g}$ ) for $15 \mathrm{~min}$ at $4{ }^{\circ} \mathrm{C}$. All further manipulation was done at this temperature. After centrifugation, the supernatant was filtered on a Touzart and Matignon filter $n^{\circ} 5$ and then centrifuged $(14500 \times \mathrm{g})$ again for $30 \mathrm{~min}$. The sediment was redissolved in saline and the suspension centrifuged under the same conditions. The sediment was reprocessed twice more by this method. The final sediment was deep-frozen until further assay. The final bacterial concentration was about 50 times higher than in the fresh feces.

The bacterial population was counted in an anaerobic chamber as well as in a long tube $(8 \times 40 \mathrm{~mm})$, in only one sample of growing pig feces per diet.

3. - Analytical techniques. - All the products studied (meconium, various feces and bacteria) were lyophilized and their dry matter $\left(24 \mathrm{~h}\right.$ in an oven at $104^{\circ} \mathrm{C}$ ), total nitrogen (Kjeldhal method) and amino acid (according to Pion and Fauconneau, 1966) contents determined as in our previous study (Darcy, Laplace and Duée, 1982). The diaminopimelic acid (DAPA) content of all samples was assayed systematically using hydrolysates prepared according to the performic oxidation required for sulphur amino acid assay. DAPA was assayed using a modification of the method of Mzik et al. (1978). When very small amounts of the samples were available, only the amino acid composition was determined.

4. - Presentation of results. - As previously (Darcy, Laplace and Duée, 1982 and 1983) conventional abbreviations were used to designate the amino acids. 


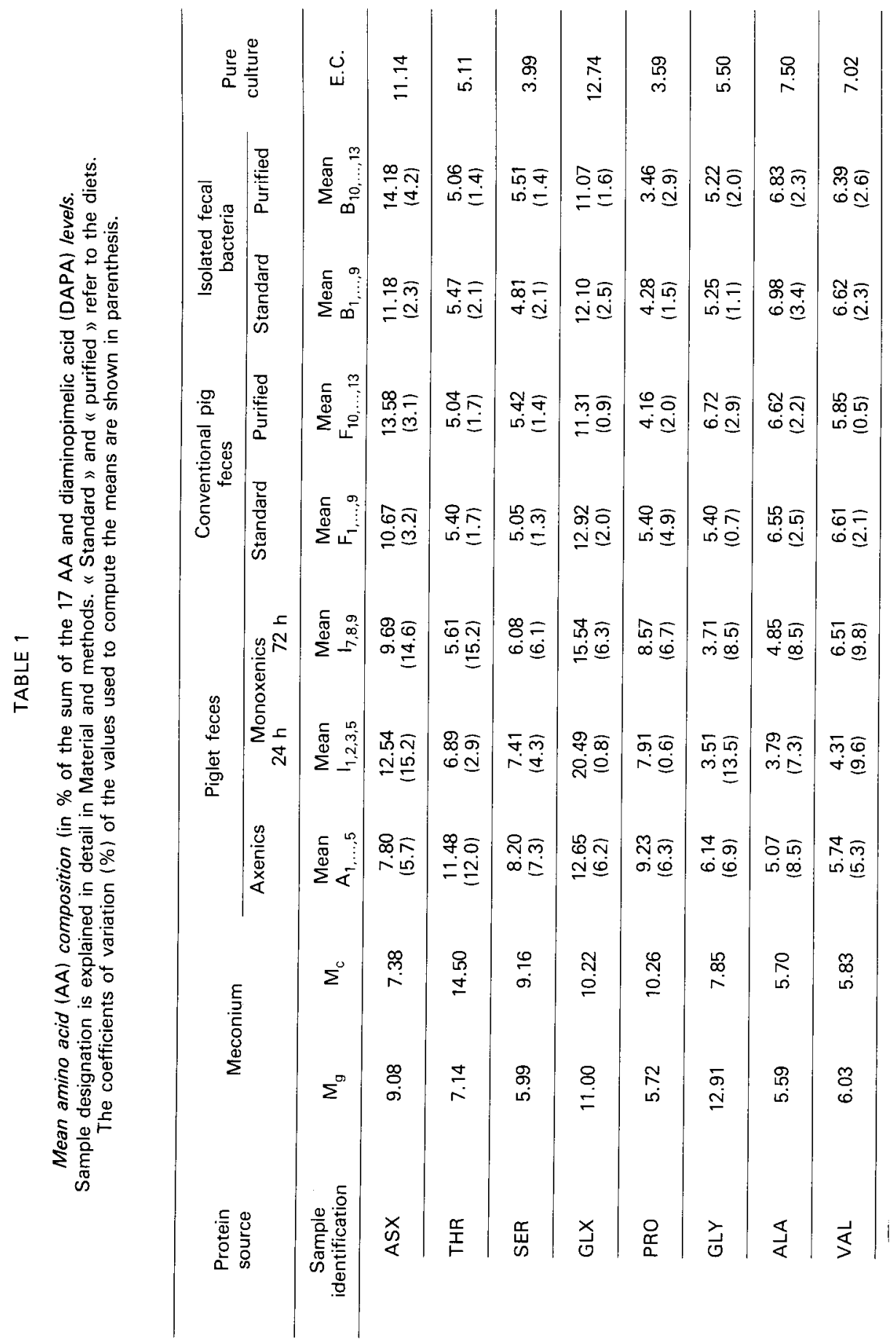




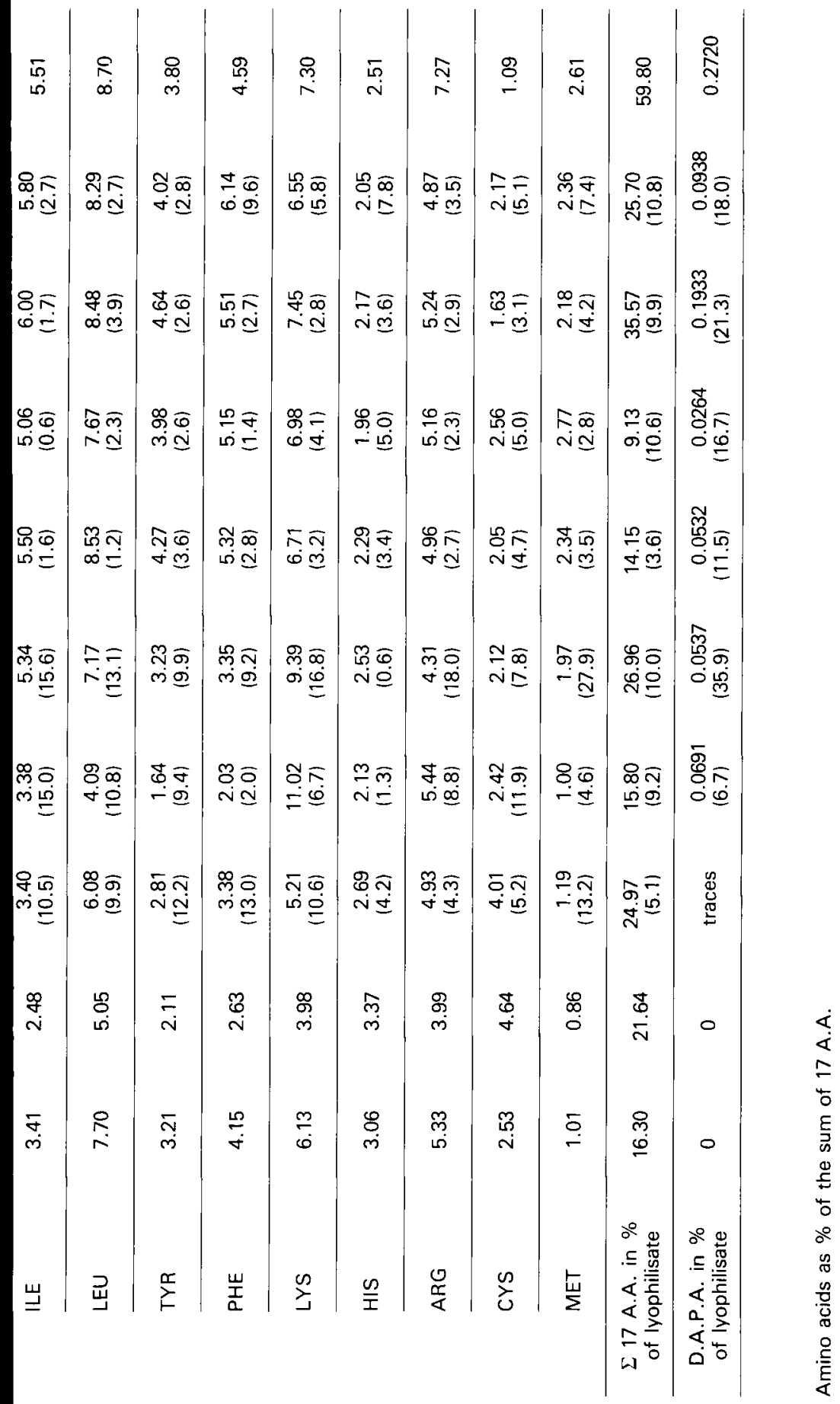


The amino acid compositions of the various samples have been compared two by two by calculating the $\chi^{2}$ distance, as already described by Guilloteau et al. (1980) and Darcy, Laplace and Duée (1983). A method of correspondance analysis was also used to make an overall comparison of the amino acid composition of the various proteins studied (Guilloteau, Sauvant and Patureau-Mirand, 1983 ; Darcy, Laplace and Duée, 1983). The main characteristics of this mathematical method of data analysis are: 1) two samples with similar amino acid compositions are projected close together on the axes or planes on which they are represented ; 2) the proximity of the projection points of an individual amino acid and of a sample indicates that the latter can be identified by its proportion of the given amino acid. For clear illustration (fig. 2), amino acid projections, on the one hand, and samples on the other are shown separately with the axes as a common reference.

\section{Results.}

\section{1. - Amino acid composition of the various protein sources (table 1).}

A comparative study of the meconium samples showed a wide difference in their respective amino acid compositions. Small intestine meconium was particularly rich in GLY, LEU and LYS ; large intestine meconium contained high levels of THR, SER, PRO and CYS. DAPA content in these samples was zero. The feces of axenic piglets had a mean amino acid composition resembling more closely that of colonic meconium than small intestine meconium; these feces contained high levels of THR, SER, PRO and CYS and the DAPA level was undetectable.

The mean fecal compositions of monoxenic piglets are given separately in table 1 according to the time-lag ( $24 \mathrm{~h}$ at most or $72 \mathrm{~h}$ at most) between inoculation and collection. As compared to the composition of axenic piglet feces, those of monoxenic piglets were generally characterized by higher levels of ASX $(A S P+A S N), G L X(G L U+G L N)$ and LYS and by lower levels of THR and GLY. However, there was a higher proportion of total amino acids in the lyophilized samples of feces collected around $72 \mathrm{~h}$ after inoculation, as compared to those collected after $24 \mathrm{~h}$. DAPA levels were of the same order of magnitude in both groups.

The amino acid composition of holoxenic growing pig feces differed very little with the diet. The feces of pigs given the purified diet showed a lower concentration of amino acids than those of pigs given the standard diet. The amino acid concentration was also lower for bacterial isolates from pigs given the purified diet than for those from pigs fed the standard diet. A similar DAPA level was recorded for monoxenic piglet feces and feces of pigs fed a standard diet. But the latter was twice as high as the DAPA level in feces of pigs fed a semi purified diet. There was also a large difference between the respective DAPA concentration of the bacterial isolates (standard $v s$ purified).

The amino acid composition of isolated fecal bacteria did not differ widely according to the diet; moreover it did not differ much from that of a pure $E$. coli culture, which however has a higher ARG content. The DAPA content of the $E$. 


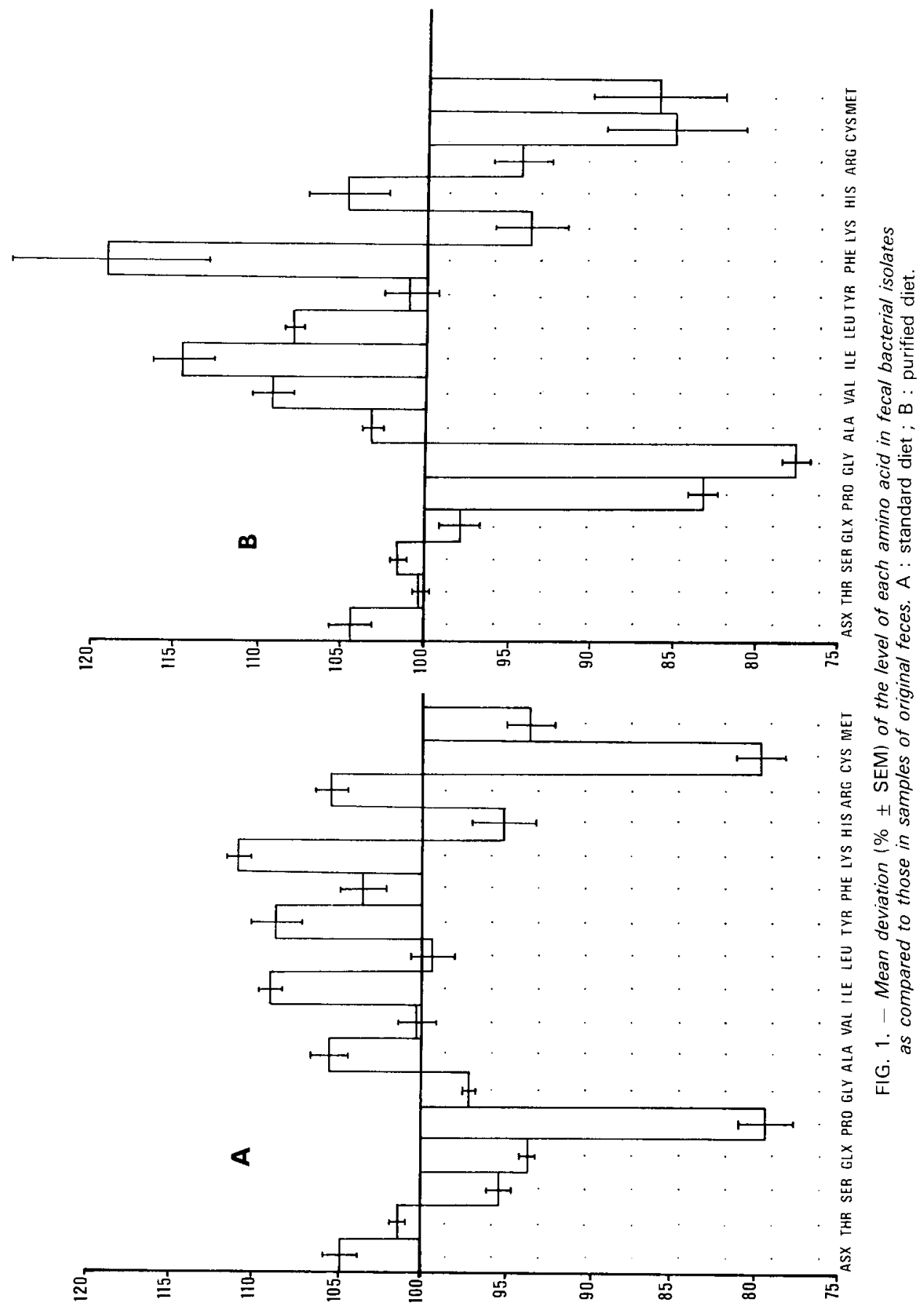


coli sample was 1.5 to 3 times higher than that measured in the isolated fecal bacteria.

\section{2. - Influence of bacteria on the composition of fecal amino acids.}

A comparison of the amino acid compositions of feces and the corresponding bacterial isolates (table 1) showed no particular differences. Beyond this first approach, the comparison of paired samples (feces-bacterial isolate) permitted us to describe the deviation of the level of each amino acid in the bacterial isolate for each diet from that recorded for the sample of original feces (fig. 1). These deviations were usually about 5 to $10 \%$ for the standard diet and they reached $20 \%$ for PRO and CYS. Deviations of about 10 to $20 \%$ (PRO, GLY, ILE, PHE, CYS, MET) occurred a little more often with the purified diet.

The proportion of bacterial protein in the fecal protein was estimated using DAPA ratios in relation to total nitrogen. In the isolated fecal bacteria these mean ratios were 0.0299 (standard diet) and 0.0194 (semi-purified diet). In feces, the corresponding mean ratios were 0.0191 and 0.0125 , which gave a bacterial protein proportion (in fecal protein) of $64.7 \pm 2.7 \%$ for the standard diet (coefficient of variation, $\mathrm{CV}=12.3 \%$ ) and of $65.7 \pm 4.7 \%$ for the purified diet (CV = $14.2 \%)$.

Compared with these estimates based on analytical techniques, counting the bacterial population gave rather different values depending on the diet. In pigs given the standard diet, we found $1.3 \times 10^{10}$ bacteria/g of fresh feces and the species were highly diversified. In those given a semi-purified diet, we found $2.6 \times 10^{9}$ bacteria $/ g$, i.e. 5 times less, with a much smaller range of species.

\section{3. - Comparison of samples and estimate of theoretical compositions.}

We judged the overall similarity of the amino acid compositions of the samples two by two, using a computation of the $\chi^{2}$ distance (table 2). This computation confirmed the difference already mentioned between the two meconium sources and the fact that the individual or mean composition of axenic piglet feces more or less resembled that of the colonic meconium. Inoculating only one type of bacterium ( $E$. coli) into the axenic animals considerably changed the fecal amino acid composition within the first $24 \mathrm{~h}$. After $72 \mathrm{~h}$, the amino acid composition of monoxenic piglet feces was much closer to that of E.coli than $24 \mathrm{~h}$ after inoculation. The $\chi^{2}$ calculation also confirmed the slight difference in the fecal amino acid composition according to diet. Thus, individually or together, the total feces and their isolated bacteria were very similar with the two diets, but especially with the standard diet. Based on their amino-acid composition, the two types of bacterial isolate were closer than were the homologous feces. On the whole, the bacterial isolates obtained with the standard diet were closer to the composition of pure $E$. coli culture.

The same computation was used to find the combination of two sources that gave the theoretical composition which most resembled a third type of sample 


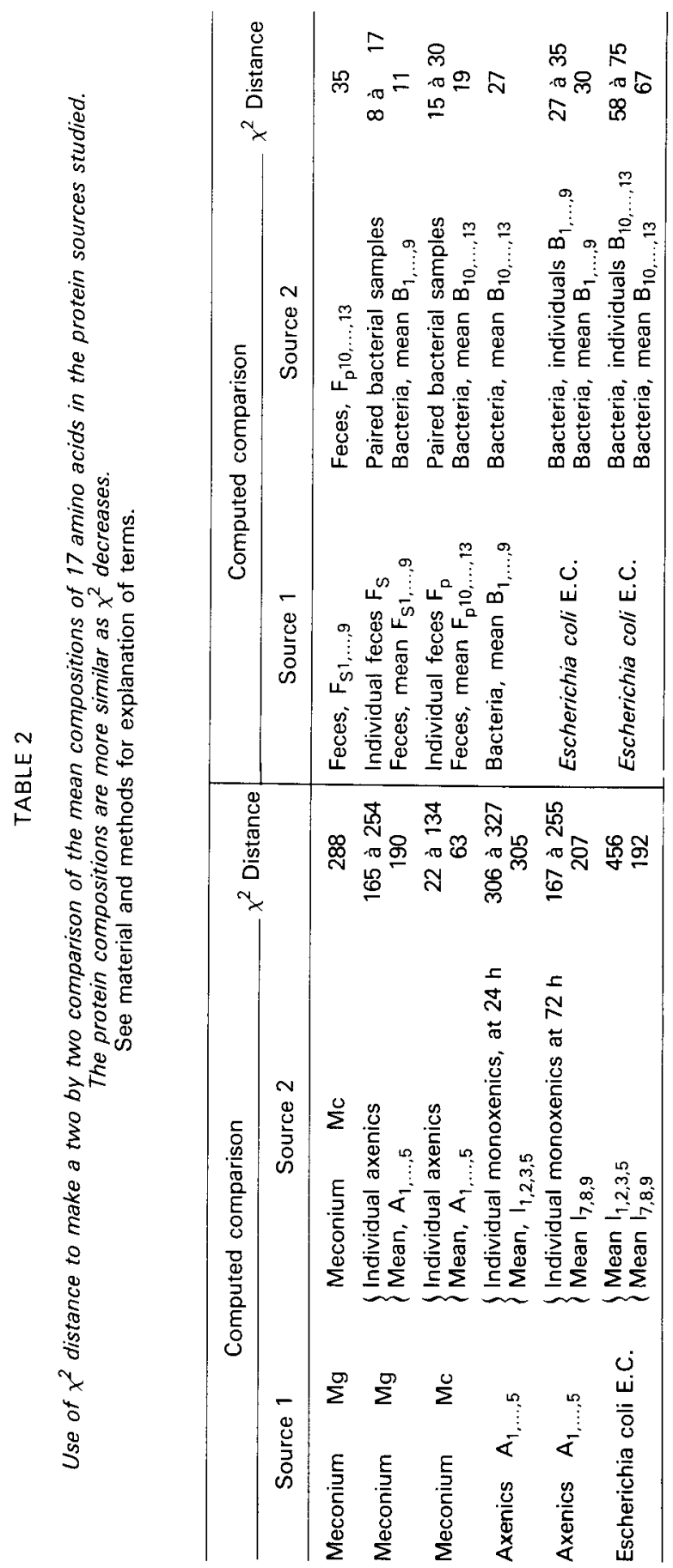


(table 3) : the reconstitution of the fecal amino acid composition in monoxenic subjects, using variable proportions of pure $E$. coli and one of the three pure sources of endogenous protein (axenic, meconiums), only gave a mediocre estimate (high $\chi^{2}$ distances). However, between 24 and $72 \mathrm{~h}$ after inoculation, the estimated proportion of $E$. coli in the sample composition increased and the estimate improved (lower $\chi^{2}$ for monoxenics at $72 \mathrm{~h}$ ). The same type of computation led to very good estimates for the feces of one diet or the other, when using homologous fecal bacteria and endogenous protein sources.

Compared with this method in which the samples were used two by two for computation, correspondance analysis allowed us to place all the samples in relation to the different amino acids in the plane defined by the two main axes corresponding to 59 and $25 \%$, respectively, of the total variance (fig. 2). The contributions of the different amino acids to determination of the axes showed that axis 1 opposed samples with higher PHE, LEU and TYR contents to those with high

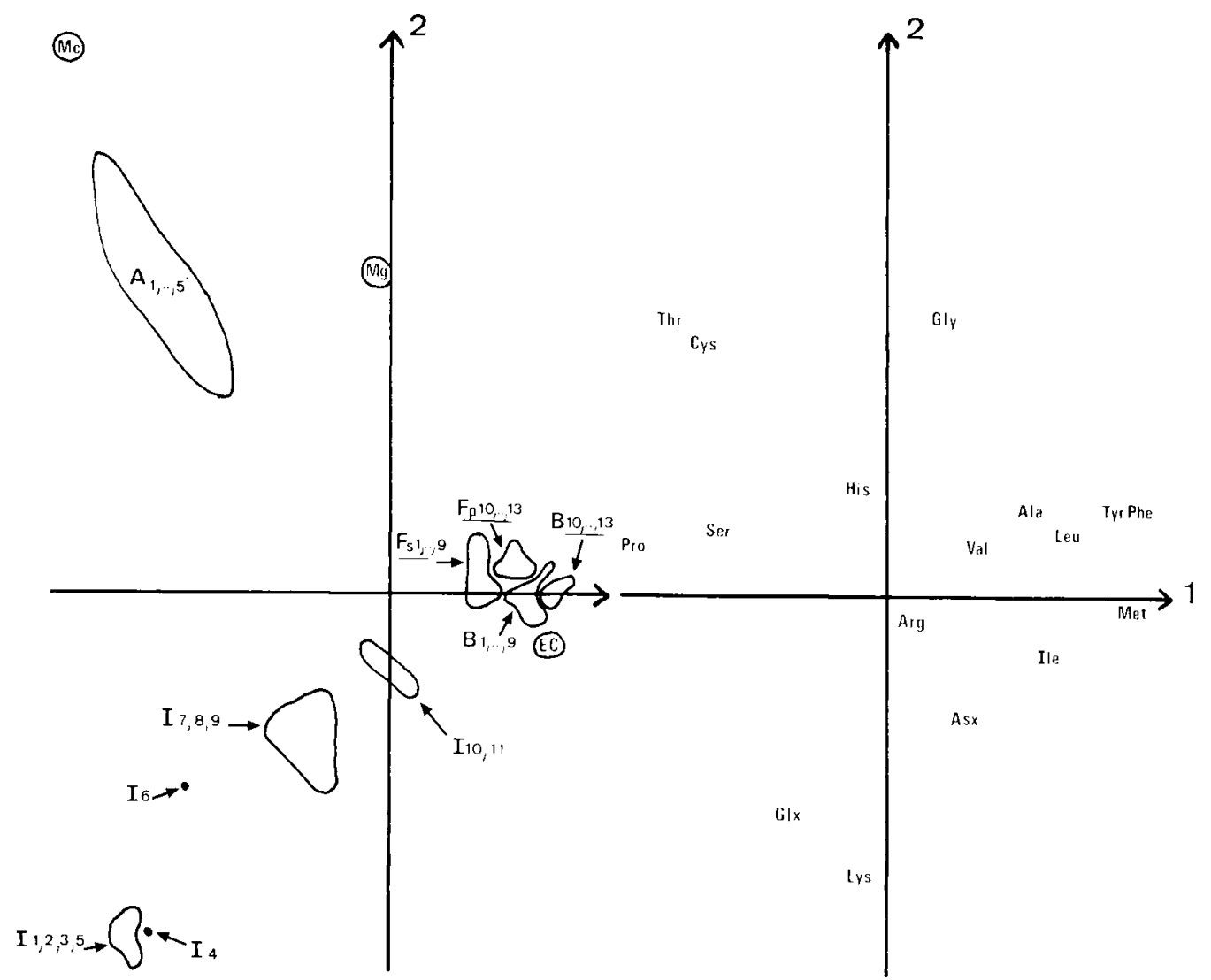

FIG. 2. - Graph plot of the results of correspondance analysis in the plane defined by the first two factors. On the left : projection areas of sample points; On the right : representation of 17 amino acid points.

For explanation, see last paragraph in Material and Methods. 


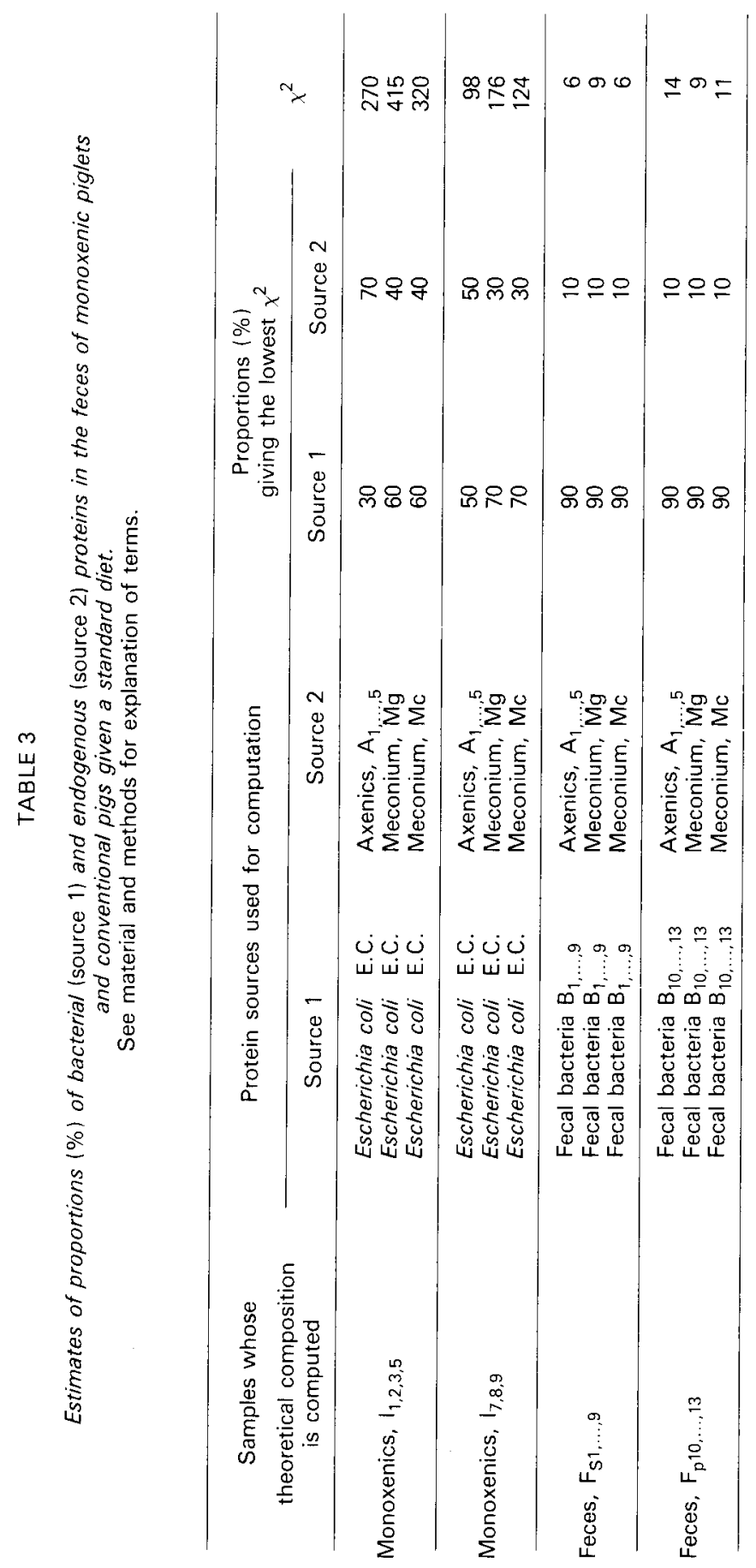


levels of PRO, THR, SER and GLX. Axis 2 opposed samples with high THR and GLY contents to those rich in GLX and LYS. This overall presentation clearly distinguishes three main groups of samples : (1) those that could be considered as pure or almost pure endogenous products $\left(^{*}\right)$ i.e. meconiums and axenics ; (2) products with a very high content of bacterial proteins : $E$. coli, bacterial isolates and the feces themselves; (3) samples which, although taken from axenic subjects inoculated with $E$. coli, no longer resembled the axenics but not yet bacteria, the spread of representative sample points corresponding to development in time from day 1 after inoculation $\left(I_{1,2,3,5}\right)$ to $48 \mathrm{~h}\left(I_{6}\right), 72 \mathrm{~h}\left(I_{7,8,9}\right)$, and even $96 \mathrm{~h}$ for mixture samples $\left(I_{10,11}\right)$.

\section{Discussion.}

\section{Compared compositions of the different protein sources.}

The above findings based on correspondance analysis summarize all the observations concerning the ratios between the 17 amino acids common to all living cells. We shall now discuss these compositions in more detail and compare them with data in the literature.

In the case of endogenous proteins there was no indication of the variability of individual meconium samples. On the other hand, there was considerable variability in the fecal amino acid composition of axenic piglets. The size of the projection area in the plane suggests that the feces of axenic subjects contained very variable proportions of small intestine and large intestine endogenous proteins. $A$ priori, these proteins could have been diluted by a residual exogenous fraction, but this fraction was certainly very small, considering the very high digestibility of milk protein. However, it is remarkable that there was more variability in the amino acid composition of axenic feces than in that of conventional feces which included an additional bacterial component besides endogenous and exogenous elements. This shows to what extent fecal bacteria can mask all other sources of variation. Another aspect is the wide overall difference in amino acid composition between the two types of piglet meconium, as shown by the high $\chi^{2}$ distance. The composition of axenic feces is far from that of the two types of meconium (table 2), but relatively close to the mean composition of the two meconiums $\left(\chi^{2}=54\right)$. This $\chi^{2}$ value is similar to that recorded $\left(\chi^{2}=43\right)$ when comparing the feces of our axenic piglets with calf meconium of non-specified anatomical origin (Grongnet et al., 1981) or when comparing $\left(\chi^{2}=54\right)$ these same axenic piglet feces with axenic lamb feces (Combe and Pion, 1977). Our very pure endogenous sources (meconium, axenic piglet feces) can also be compared to samples obtained from older conventional pigs and considered as representative of an endogenous fraction, such as effluent of perfused isolated intestinal loop (Buraczewska, 1979) and duodenal or jejunal mucus recovered from various sites in small intestine (Darcy, Laplace and Duée, 1983). These two types of products, that are

$\left(^{*}\right)$ The digestibility of milk protein is considered as almost total. 
rather similar to one another $\left(\chi^{2}=54\right)$ are practically superimposed in the correspondance analysis plane on the feces of conventional pigs given a protein-free diet (Darcy, Laplace and Duée, 1983), the latter feces being another type of material usually considered as representative of the composition of the endogenous fraction. However, the mean amino acid composition of the mucus of conventional pig small intestine is very different from that of the meconium of the small intestine $\left(\chi^{2}=154\right)$ or colon $\left(\chi^{2}=256\right)$. This shows the important contribution of the flora to the amino acid composition of the mucus of conventional pig intestine.

This influence is well illustrated (fig. 2) by the close nearness of sample projections such as conventional pig feces, isolated fecal bacteria and pure $E$. coli culture. The overall variability of these data is very low. However, the purified diet led to results on feces and bacterial isolates that were slightly different from those obtained with the standard diet. The fecal bacterial isolates with a standard diet, as studied by Mason, Just and Bech-Andersen (1976) and by us, had almost identical compositions $\left(\chi^{2}=4\right)$; those obtained with the purified diet deviated slightly $\left(\chi^{2}=21\right.$ or 27 ) depending on the comparison reference. It should also be noted that the amino acid composition of pig fecal bacteria with a standard diet is relatively close $\left(\chi^{2}=41\right)$ to the mean composition of 22 bovine rumen microorganisms (Purser and Buechler, 1966).

Compared to the two types of populations already mentioned, the projection of monoxenic piglet feces has a totally different location. It is not surprising that the development of a bacterial population, from the time it is inoculated, initiates a gradual change in the amino acid composition of the samples towards that of the bacterium inoculated or that of conventional feces ; however, it is surprising that this change is not initiated from a basal axenic type of composition. This brings into question the possibility of a large and early effect of inoculation on the amino acid composition of fecal proteins in these piglets. It is as if the inoculation initiated, during the first $24 \mathrm{~h}$, an unidentified process, that caused the very high levels of GLX and LYS which characterized only these samples.

\section{Estimate of the quantitative importance of bacterial protein in feces.}

The particular impact of flora has been emphasized above. However, the level of DAPA - an amino acid found in the membrane mucopeptides of many bacteria (Work and Dewey, 1953) - needs some discussion. The absence of DAPA in meconium samples was expected as samples were taken immediately at birth before any oral contamination. Traces of DAPA found in axenic feces may be due to the fact that the milk used to feed the piglets was sterilized by irradiation, leaving dead bacteria in the ingested product. There is also the question of the value of DAPA as an indicator of bacterial proteins, in view of the density of the bacteria population and the variation in DAPA level (in relation to nitrogen) amongst the populations or strains studied.

The amount of DAPA in the lyophilized samples of isolated fecal bacteria varied twofold, depending on the type of diet ingested by the animal. With the standard diet, we estimated (microscopic examination) a 5-times higher popula- 
tion corresponding to a doubling of the concentration of DAPA. However, microscopic examination also showed that the species contained in the populations are different. DAPA level varies with the bacterial strain and may even be zero in some $\left({ }^{*}\right)$ populations (Work and Dewey, 1953; Dufva et al., 1982). Table 4 gives some values of DAPA level obtained in the present study or found in the literature, in relation to either total nitrogen or to the sum of 18 amino acids. It is seen that rumen bacteria, isolated or in pure culture, generally have higher DAPA levels than pig fecal bacteria. Dufva et al. (1982), studying these rumen bacteria, have shown the variability in DAPA levels from one bacterial species to another ; these authors also showed that the sugar content of the medium affected the DAPA level in the 9 species cultured. This agrees with the effect of diet recorded for rumen (Dufva et al., 1982) and pig feces (table 4) bacterial isolates.

\section{TABLE 4}

Diaminopimelic acid (DAPA) levels in bacteria isolated from the digestive tract or cultured.

\begin{tabular}{|c|c|c|c|}
\hline Fecal bacteria of pig & DAPA/N & \multicolumn{2}{|c|}{ DAPA $\%$ of $\Sigma 18$ AA } \\
\hline \multicolumn{4}{|l|}{ in : the present work } \\
\hline Standard diet & 0.0299 & & 0.52 \\
\hline Purified diet & 0.0194 & & 0.35 \\
\hline \multicolumn{4}{|l|}{ in : Poppe and Meier (1983) } \\
\hline Wheat-casein-straw diet & 0.0376 & & 0.65 \\
\hline Wheat-casein diet & 0.0398 & & 0.72 \\
\hline Corn diet & 0.0375 & & 0.65 \\
\hline \multicolumn{4}{|l|}{ in : Mason, Just and Bech-Andersen (1976) } \\
\hline Cornstarch-barley-soya diet & - & & 0.23 \\
\hline Potato starch-barley-soya diet & - & & 0.27 \\
\hline \multicolumn{2}{|l|}{ Mixed rumen bacteria } & \multicolumn{2}{|l|}{$\mathrm{DAPA} / \mathrm{N}$} \\
\hline \multicolumn{4}{|l|}{ in : Dufva et al. (1982) } \\
\hline Concentrate diet & \multicolumn{3}{|c|}{0.034} \\
\hline Coarse forage diet & \multicolumn{3}{|c|}{0.045} \\
\hline $\begin{array}{l}\text { in : Hutton, Bailey and Annison (1971) } \\
\text { Sheep rumen }\end{array}$ & \multicolumn{3}{|c|}{0.0524} \\
\hline Bacteria in pure culture : & \multicolumn{3}{|c|}{ DAPA/N } \\
\hline in : the present work & \multirow{2}{*}{\multicolumn{3}{|c|}{0.0248}} \\
\hline Escherichia coli & & & \\
\hline in : Dufva et al. (1982), mean of 9 different bacteria & \multirow{2}{*}{\multicolumn{3}{|c|}{0.0471}} \\
\hline Medium with low sugar content & & & \\
\hline Medium with high sugar content & \multicolumn{3}{|c|}{0.055} \\
\hline
\end{tabular}

(*) Staphylococcus aureus, Micrococcus lysodeikticus, Sarcina lutea, Streptococcus pneumoniae, Streptococcus pyogenes, Streptococcus faecalis, Leuconostoc mesenteroides, Streptococcus bovis, etc... 
This group of values demonstrates the wide variability of the DAPA : bacterial nitrogen ratio. Thus, a single reference value of this ratio cannot be used to estimate the proportion of bacterial nitrogen in a sample. When using the ratio truly corresponding to the bacterial population in the samples studied, a correct proportion could be obtained. Under these conditions, the estimate of the contribution of bacterial nitrogen to fecal nitrogen for a given diet shows some interand intra-individual variability (coefficients of variation : 12 to $14 \%$ ). But it is remarkable that the estimated proportion of bacterial nitrogen with the two diets studied is similar (65 to $66 \%$ of fecal nitrogen). This observation must be compared with the bacterial counts (5 times more with the standard diet) and amounts of DAPA in the samples of feces or bacterial isolates: (1) the population was counted on only one sample per diet, but to obtain the relationship between this count and the proportion of bacterial proteins, the volume, density and nitrogen content of these bacteria must be considered; this has been done by Mason, Just and Bech-Andersen (1976) who reported much lower values than those based on DAPA or nucleic acid assay. The number of uncertainties relative to the number of hypotheses makes this solution very hazardous and no conclusions can be drawn ; (2) the proportion of DAPA in the samples was two times higher with the standard than with the purified diet for the feces as well as for the corresponding bacterial isolates. But the same parallelism between feces and isolates was found, as the nitrogen levels were 1.3 times higher with the standard than with the purified diet. It is thus to be expected that the proportion of bacterial nitrogen in the total nitrogen, i.e. the relationship between the DAPA : nitrogen ratio of bacteria over the DAPA : nitrogen ratio of feces, would be the same for both diets.

While estimates using DAPA as an index are compatible with the various results reported, it does not mean that these estimates are completely reliable. Excepting extrapolation based on counting, the use of another index based on ribonucleic acid (RNA) assay led to markedly different results with the same diet in the work of Mason, Just and Bech-Andersen (1976): $58 \%$ (RNA) vs $91 \%$ (DAPA) for a cornstarch diet ; $51 \%$ vs $87 \%$ for a potato starch diet.

Finally, apart from the divergence of these methods based on the assay of a more or less specific bacterial marker, the estimate in the present study, based on comparisons of the compositions of 17 amino acids also led to similar values with the two diets studied. However, in the latter case, the estimated proportion of bacterial nitrogen reached $90 \%\left(\chi^{2}\right.$ method) vs $65-66 \%$ (DAPA method).

\section{Conclusions.}

The present study describes the characteristic amino acid composition of strictly endogenous (meconium) or bacterial (E. coli) proteins. The composition of an intermediate range of samples containing either a dominant endogenous fraction (axenic piglet feces) or a bacterial fraction (fecal bacteria isolates) was also reported. It was shown that the composition of exclusively endogenous products differed somewhat from that of conventional samples (mucus, mucosa) usually 
considered as representative of this endogenous fraction. Finally, this study confirms that bacterial proteins constitute the major part of fecal proteins in conventional pigs. However, it is difficult to make a strict estimate since values ranging between 65 and $90 \%$ were found in the same conditions, according to the method chosen.

Reçu en juillet 1985.

Accepté en septembre 1985

Résumé. Protéines des contenus digestifs chez le porc : composition en acides aminés de fractions endogènes, bactériennes et fécales.

Dans le cadre d'études de digestibilité, il est nécessaire d'estimer la part respective des fractions exogène, endogène et bactérienne présentes dans les digesta ou les fèces. Pour les protéines, l'estimation est fondée sur la comparaison des compositions en acides aminés observées à celles de sources de référence. Le présent travail décrit la composition de protéines endogènes ou microbiennes, pures ou purifiées : méconium d'intestin grêle ou de côlon de porcelet, fèces de porcelets axéniques; bactéries isolées de fèces de porcs recevant un régime standard ou purifié, et culture pure d'E. coli. Sont aussi étudiées les compositions de fèces de porcelets monocontaminés, et de fèces de porcs conventionnels pour les deux types de régimes. A partir des données analytiques (17 acides aminés), on a procédé à des comparaisons globales des compositions par.la méthode des distances de $\varkappa^{2}$ et par analyse factorielle des correspondances. II apparaît que la composition des produits exclusivement endogènes diffère quelque peu de celle d'échantillons classiquement considérés comme représentatifs de cette fraction (mucus, muqueuse). Enfin, il est confirmé que les protéines bactériennes constituent la majeure partie des protéines fécales chez des porcs conventionnels. Mais une estimation rigoureuse est très difficile : celle qui est fondée sur le dosage de l'acide diamino-pimélique conduit à évaluer à $65 \%$ la proportion de protéines bactériennes ; le calcul de la distance du $\chi^{2}$ fournit une estimation de $90 \%$ dans les mêmes conditions expérimentales.

\section{References}

BURACZEWSKA L., 1979. Secretion of nitrogenous compounds in the small intestine of the pigs. Acta physiol. pol., 30, 319-326.

COMBE E., PION R., 1977. Influence de l'axénie sur la composition en acides aminés des fèces chez le rat et l'agneau. Ann. Biol. anim. Bioch. Biophys., 17, 633-636.

DARCY B., LAPLACE J. P., DUEE P. H., 1982. Digestion des protéines dans l'intestin grêle chez le porc. 1) Digestibilité des acides aminés selon la source de protéines d'un régime à base d'amidon de maïs purifié. Ann. Zootech., 31, 279-300.

DARCY B., LAPLACE J. P., DUEEE P. H., 1983. Digestion des protéines dans l'intestin grêle chez le Porc. 2) Composition en acides aminés des digesta : influence de la source de protéines d'un régime à base d'amidon de mais purifié et variations postprandiales. Ann. Zootech., 32, 315-340.

DUFVA G. S., BARTLEY E. E., ARAMBEL M. J., NAGARAJA T. G., DENNIS S. M., GALITZER S. J., DAYTON A. D., 1982. Diaminopimelic acid content of feeds and rumen bacteria and its usefulness as a rumen bacterial marker. J. Dairy Sci, 65, 1754-1759.

GRONGNET J. F., PATUREAU-MIRAND P., TOULLEC R., PRUGNAUD J., 1981. Utilisation des protéines du lait et du lactosérum par le jeune veau pré-ruminant. Influence de l'âge et de la dénaturation des protéines du lactosérum. Ann. Zootech., 30, 443-464.

GUILLOTEAU P., PATUREAU-MIRAND P., TOULLEC R., PRUGNAUD J., 1980. Digestion of milk protein and methanol-grown bacteria protein in the preruminant calf. 2) Aminoacid composition of ileal digesta and faeces and blood levels of free aminoacids. Reprod. Nutr. Dévelop., 20, 615-629. 
GUILLOTEAU P., SAUVANT D., PATUREAU-MIRAND P., 1983. Methods of comparing amino acid composition of proteins : application to undigested proteins in the preruminant calf. Ann. Nutr. Metab., 27, 457-469.

HUTTON K., BAILEY F. J., ANNISON E. F., 1971. Measurement of the bacterial nitrogen entering the duodenum of the ruminant using diaminopimelic acid as a marker. Br. J. Nutr., 25, 165173.

MASON V. C., 1969. Some observations on the distribution and origin of nitrogen in sheep faeces, J. agric. Sci., Cambridge, 73, 99-111.

MASON V. C., JUST A., BECH-ANDERSEN S., 1976. Bacterial activity in the hind gut of pigs. 2) Its influence on the apparent digestibility of nitrogen and amino acids. Z. Tierphysiol. Tierernähr. Futtermittelkde, 36, 310-324.

MZIK J., HOGAN J. P., LINDSAY J. R., DAVIS P., 1978. A rapid chromatographic determination of diaminopimelic acid with lithium citrate buffers. J. Chromatography, 152, 269-271.

PION R., FAUCONNEAU G., 1966. Les acides aminés des protéines alimentaires. Méthodes de dosage et résultats obtenus. Cahier $\mathrm{n}^{\circ} 6$. Aminoacides, peptides, protéines, 157-175, AEC, Commentry.

POPPE S., MEIER H., 1983. Zur Aminosaürenzusammensetzung der Kotbakterien beim Schwein. Arch. Tierernähr., 33, 151-154.

PURSER D. B., BUECHLER S. M., 1966. Aminoacid composition of rumen organisms. J. Dairy Sci., 49, 81-84.

SMITH R. H., 1969. Reviews of the progress of dairy science. Section G. General. Nitrogen metabolism and the rumen. J. Dairy Res., 36, 313-331.

SOUFFRANT W. B., KÖHLER R., GEBHARDT G., 1982. Détermination de l'azote endogène dans les contenus digestifs par la technique isotopique $\left({ }^{15} \mathrm{~N}\right)$. In LAPLACE J. P., CORRING T., RERAT A., Physiologie digestive chez le porc, 175-187, Les Colloques de I'I.N.R.A. $\mathrm{n}^{\circ} 12$, INRA Publ. Ed.

SYNGE R. L. M., 1953. Note on the occurrence of diaminopimelic acid in some intestinal microorganisms from farm animals. J. gen. Microbiol., 9, 407-409.

WORK E., DEWEY D. L., 1953. The distribution of $\alpha, \epsilon$-diaminopimelic acid among various microorganisms. J. gen. Microbiol., 9, 394-409. 